\title{
ПАТОГЕНЕТИЧЕСКАЯ РОЛЬ КЛЕТОК КРОВИ И МЕДИАТОРОВ ВОСПАЛЕНИЯ В СОСУДИСТОЙ ДИСФУНКЦИИ У ЛИЦ ПОЖИЛОГО ВОЗРАСТА НА ПРИМЕРЕ COVID-19
}

\section{PATHOGENETIC ROLE OF BLOOD CELLS AND INFLAMMATORY MEDIATORS IN VASCULAR DYSFUNCTION IN ELDERLY PERSONS BY EXAMPLE COVID-19}

\section{S. Rukavishnikova A. Pushkin \\ T. Akhmedov U. Saginbaev E. Davydova Ju. Evnevich}

Summary. The beginning of 2020 was marked by the declaration of a pandemic of a new coronavirus infection caused by the SARS-CoV-2 virus. This disease poses a danger to certain categories of citizens, one of the risk groups includes persons of older age groups. The pathogenesis of this infectious disease is characterized by preferential damage to the tissues of the lower respiratory tract, lung parenchyma, as well as vascular dysfunction. Increased permeability of cell membranes and vascular walls was revealed; relatively late immune response formation with the phenomenon of "cytokine storm." The aim of the present study was to identify the distinctive features of hematological indices in elderly patients divided into two groups. The first group included persons with pneumonia caused by SARS-CoV-2, the second patients with pneumonia of a different etiology. Statistically significant differences were found in individual erythrocyte, leukocyte and platelet indices.

Keywords: COVID-19, cytokines, old age, blood cells.

\author{
Рукавишникова Светлана Александровна \\ Д.б.н., дочент, СПб ГБУЗ «ГМПБ № 2» \\ (2. Санкт-Петербург) \\ kdlb2@yandex.ru \\ Пушкин Александр Сергеевич \\ К.м.н., доцент, СПб ГБУЗ «ГМПБ № 2» \\ (2. Санкт-Петербург) \\ Ахмедов Тимур Артыкович \\ К.м.н., дочент, СПб ГБУЗ «ГМПБ № 2» \\ (2. Санкт-Петербург) \\ Сагинбаев Урал Ринатович \\ К.б.н., СПб ГБУЗ «ГМПБ № 2» (2. Санкт-Петербург) \\ starosta-mpf@mail.ru \\ Давыдова Елена Петровна \\ Врач, СПб ГБУЗ «ГМПБ № 2» (2. Санкт-Петербург) \\ Евневич Юлия Владимировна \\ Врач-бактериолог, СПб ГБУЗ «ГМПБ № 2» \\ (2. Санкт-Петербург)
}

Аннотация. Начало 2020 года ознаменовалось объявлением пандемии новой коронавирусной инфекции, вызванной вирусом SARS-CoV-2. Данное заболевание представляет опасность для определенных категорий граждан, к одной из групп риска относятся лица старших возрастных групп. Патогенез данного инфекционного заболевания характеризуется преимущественным поражением тканей нижних дыхательных путей, паренхимы легких, а также сосудистой дисфункцией. Выявлены повышение проницаемости мембран клеток и сосудистых стенок; относительно запоздалое формирование иммунного ответа с феноменом «цитокинового шторма». Целью настоящего исследования явилось выявление отличительных особенностей гематологических индексов у пациентов пожилого возраста, разделенных на две группы. В первую группу вошли лица с пневмонией, вызванной SARS-CoV-2, во вторую - пациенты с пневмонией иной этиологии. Обнаружены статистически значимые различия по отдельным эритроцитарным, лейкоцитарным и тромбоцитарным индексам.

Ключевые слова: COVID-19, цитокины, пожилой возраст, клетки крови.

Инцидентность пневмонией с 1980-х гг. характеризуется неблагоприятной восходящей линией тренда[5]. Стоит отметить, что пневмония во всем мире занимает 4-5 место в структуре причин смерти, причем среди инфекционных заболеваний пневмонии принадлежит лидирующая позиция по данному показателю. Примечательно, что у лиц старше 60 лет уровень заболеваемости составляет 20-44 случая на 1000 населения в год, а летальность у данной категории пациентов может достигать до 50\%[5]. 
Выделенный в Китае в конце 2019 года новый штамм коронавируса, получивший официальное название SARS-CoV-2, явился еще одним этиологическим началом атипичной пневмонии. Заражение вирионамисопровождается повышением проницаемости клеточных мембран и чрезмернымпереходом жидкости, богатой альбумином, в межклеточное пространство ткани лёгкого и просвет альвеол. Далее наступает разрушениесурфактанта и, как следствие, снижение функции альвеолярного дерева, в результате резкого нарушения газообмена развивается острый респираторный дистресс-синдром [6]. Подавление и извращение функции иммунной системы данной когорты больных способствуют развитию вторичных респираторного тракта бактериальной и грибковой природы. В настоящее время механизмы развития иммунного ответа в отношении SARS-CoV-2 изучены недостаточно подробно. Необходимо подчеркнуть, что иммунитет при инфекциях, вызванных иными представителями семейства коронавирусов, нестойкий и возможно повторное заражение [1].

В возникновении и течении пневмонии существенный вклад вносят факторы риска, способные угнетать компенсаторные возможности организма. Установлено, что пожилой и старческий возраст является одним из значимых факторов риска, повышающих вероятность неблагоприятного течения и исхода пневмонии [2]. Это, прежде всего, связано с нарушениями функции иммунной системы, снижением работы мукоцилиарного клиренса, угнетением кашлевого рефлекса, а также модификацией нормальной микрофлоры. Немаловажную роль играет повышенный цитокиновый профиль у лиц старшей возрастной категории с преобладанием провоспалительных медиаторов, таких как интерлейкин-6 и фактор некроза опухоли, что усугубляется тем, что при новой коронавирусной инфекции возможно развитие такого феномена как «цитокиновый шторм». К тому же полиморбидное состояние - частый спутник лиц старшего поколения - является дополнительным отягчающим фактором в развитии пневмонии [4].

\section{Цель исслеАования}

Выявление особенностей клинического анализа крови у пациентов пожилого возраста, которым диагностирована пневмония, вызванная SARS-CoV-2.

\section{Материалы и метомы}

Проведено ретроспективное исследование клинического анализа крови (ОАК) 83 пациента пожилого возраста (60-74 года), у которых диагностированапневмония различной этиологии. В исследование включены пациенты, госпитализированные в отделения СПб ГБУЗ «Городская многопрофильная больница № 2» с 28.03.2020 по 24.04.2020. Пациенты были разделены на две группы в зависимости от возбудителя пневмонии: 1 группа (К) - пациенты с пневмонией, вызванной SARS-CoV-2 (54 человека; 48,1\% мужчины, 51,9\% женщины), 2 группа (Н) - пациенты с пневмонией, вызванной иными микроорганизмами (29 человек; 55,2\% и 44,8\%, соответственно).

Критериями включения явились: наличие пневмонии, отсутствие сопутствующих острых и хронических заболеваний в стадии декомпенсации. Критерия исключения - наличие иных острых и хронических заболеваний в стадии декомпенсации.

Для исследования ОАК бралась кровь методом венепункции из кубитальной вены в вакуумные пробирки, содержащие ЭДТА (этилендиаминтетраацетат). Забор биологического материала проводился полностью в соответствии с требованиями ведения преаналитического этапа гематологического исследования. Анализ проводился автоматическим гематологическим анализатором Cell-DynSapphire, производства AbbottLaboratories (США). Исследование ОАК проводилось в день госпитализации.

Статистическая обработка полученных результатов проводилась с применением пакета прикладных программ Statistica 6.0.Для каждого массива данных производился расчет параметров описательной статистики: средняя арифметическая, стандартная ошибка, стандартное отклонение, медиана (Me), эксцесс, асимметричность, квартили (Q1-25\%, Q2-75\%). Характер распределения полученных результатов оценивались с использованием критерия Шапиро - Уилка. Принимая во внимание правило «трех сигм», критерий Шапиро-Уилка, значения асимметричности и эксцесса, был выявлен ненормальный характер распределения выборки. На данном основании при дальнейшем анализе применялись непараметрические методы статистической обработки.

Сравнение с применением критерия Фишерадвух групп по гендерному признаку позволило принять нулевую гипотезу $(p>0,05)$, что означает сопоставимость сравниваемых совокупностей по половому различию. Сравнение несвязанных совокупностей проводился с применением $U$-критерия Манна-Уитни.За максимально приемлемую вероятность ошибки первого рода $(p)$ приняли величину уровня статистической значимости, равную или меньшую 0,05.

\section{Результаты}

Для сравниваемых совокупностей были рассчитаны средние значения, медианы и квартили для следующих 
Таблица 1. Клинический анализ крови у пациентов пожилого возраста, у которых диагностирована пневмония, вызванная SARS-CoV-2 (группа «К») и иными возбудителями (группа «Н»).

\begin{tabular}{|l|l|l|}
\multirow{2}{*}{ Показатели ОАК } & K-группа & H-группа \\
\cline { 2 - 3 } & Me (Q1; Q3) & Me (Q1; Q3) \\
\hline WBC & $6,3(4,7 ; 8,2)^{* *}$ & $8,3(6,6 ; 9,7)^{* *}$ \\
\hline NEU & $3,8(2,5 ; 5,8)^{* *}$ & $5,8(3,8 ; 7,5)^{* *}$ \\
\hline LYM & $1,3(1,0 ; 1,9)$ & $1,4(1,1 ; 1,9)$ \\
\hline MON & $0,5(0,4 ; 0,7)$ & $0,7(0,4 ; 1,1)$ \\
\hline EOS & $0,04(0,01 ; 0,10)$ & $0,05(0,01 ; 0,18)$ \\
\hline BAS & $0,04(0,02 ; 0,06)$ & $0,04(0,02 ; 0,06)$ \\
\hline RBC & $4,5(4,2 ; 4,9)^{*}$ & $4,1(3,5 ; 4,7)^{*}$ \\
\hline HGB & $130(121 ; 140)^{*}$ & $119(100 ; 137)^{*}$ \\
\hline HCT & $40,4(36,8 ; 42,6)^{*}$ & $36,2(30,8 ; 40,6)^{*}$ \\
\hline MCV & $88,8(84,8 ; 91,2)$ & $88,0(85,5 ; 91,3)$ \\
\hline MCH & $29,0(27,5 ; 29,6)$ & $29,0(27,4 ; 30,0)$ \\
\hline MCHC & $32,7(31,9 ; 33,0)$ & $32,9(31,7 ; 33,5)$ \\
\hline RDW-CV & $11,8(11,3 ; 12,4)^{* *}$ & $13,2(12,2 ; 15,6)^{* *}$ \\
\hline PLT & $226,5(183,3 ; 264,3)$ & $240,0(159,0 ; 332,0)$ \\
\hline MPV & $7,8(6,9 ; 8,8)$ & $8,1(7,3 ; 9,2)$ \\
\hline PDW & $20,3(19,6 ; 21,3)^{*}$ & $19,8(16,6 ; 21,0)^{*}$ \\
\hline PCT & $0,18(0,15 ; 0,22)$ & $0,19(0,12 ; 0,26)$ \\
\hline
\end{tabular}

Примечание: * $-p \leq 0,05,{ }^{*}-p \leq 0,01$.

показателей: WBC (общее количество лейкоцитов), NEU (количество нейтрофилов), LYM (количество лимфоцитов), MON (количество моноцитов), EOS (количество эозинофилов), BAS (количество базофилов), RBC (количество эритроцитов), HGB (уровень гемоглобина), НСТ (гематокрит), MCV (средний объем эритроцитов), МСH (содержание гемоглобина в эритроцитах), MCHC (средняя концентрация гемоглобина в эритроцитах), RDW (ширина распределения эритроцитов по объему), PLT (количество тромбоцитов), MPV (средний объем тромбоцитов), PDW (ширина распределения тромбоцитов по объему) и РСТ (тромбокрит) (таблица).

Таким образом обнаружены статистически значимые различия по количеству лейкоцитов, нейтрофилов, эритроцитов и по объему тромбоцитов. Выявлены также характерные особенности по таким эритроцитар- ным индексам, как содержание гемоглобина, ширине распределения эритроцитов по объему и гематокриту. Стоит отметить, что различия по указанным лейкоцитарным индексам были наиболее достоверны $(p \leq 0,01)$.

Более низкие показатели количества лейкоцитов и нейтрофилов при COVID-19, вероятно, связаны с запоздалым иммунным ответом и обусловливают развитие вторичной инфекционной патологии. Изменения отдельных эритроцитарных индексов согласовываются с современными представлениями патогенеза новой коронавирусной инфекции и характерны для процессов сгущения крови. Изменения реологических свойств крови, в свою очередь, связаны с повышением проницаемости сосудистой стенки и переходом жидкой части крови из просвета сосудов в интерстициальное пространство. 


\section{Выво $\triangle \mathrm{b}$}

Проведенное исследование выявило особенности клинического анализа крови у пациентов пожилого возраста, которым диагностирована пневмония, вызванная SARS-CoV-2. Обнаруженные отличительные признаки согласуются с имеющимися данными научной литературы, в которых описываются патогенетические механизмы течения новой коронавирусной инфекции. Продемонстрированы морфологические метаморфозы иммунных клеток, что может быть связано с дисбалансом цитокиновой регуляции.

\section{ИСТОЧНИКИ \\ Финансирования}

Данная работа не имела финансирования.

Работа выполнена с соблюдением этических стандартов.

Конфликт интересов отсутствует.

\section{ЛИТЕРАТУРА}

1. Львов Д.К., Колобухина Л.В., Дерябин П.Г. Коронавирусная инфекция. Тяжелый острый респираторный синдром // Инфекционные болезни: Новости. Мнения. Обучение, 2015, № 4, С. 35-42.

2. Никонова Е.В., Чучалин А.Г., Черняев А.Л. Пневмонии: эпидемиология, классификация, клинико-диагностические аспекты // Российский медицинский журнал. 1997. № 17. С. 2.

3. Попова А.Ю. и др. Эпидемиология и профилактика внебольничных пневмоний // Инфекционные болезни: Новости. Мнения. 0бучение. 2019. № 2. С. 43-48.

4. Чубукова 0.А., Шкарин В.В. Особенности эпидемиологии внебольничных пневмоний с сочетанной патологией // Медицинский альманах. 2017. Т. 49. № 4. C. 149-156.

5. Яковенко 0.Н., Кравченко Н.А. Особенности эпидемиологии внебольничных пневмоний // Сибирский медицинский журнал. 2014. № 2. С. 8-11.

6. Hussin A. Rothan, Sidappa N. Byrareddy The epidemiology and pathogenesis of coronavirus disease (COVID-19) outbreak // J. Autoimmun, 2020, 109, 44-48.

( Р Рукавишникова Светлана Александровна ( kdlb2@yandex.ru ), Пушкин Александр Сергеевич,

Ахмедов Тимур Артыкович, Сагинбаев Урал Ринатович ( starosta-mpf@mail.ru ), Давыдова Елена Петровна, Евневич Юлия Владимировна.

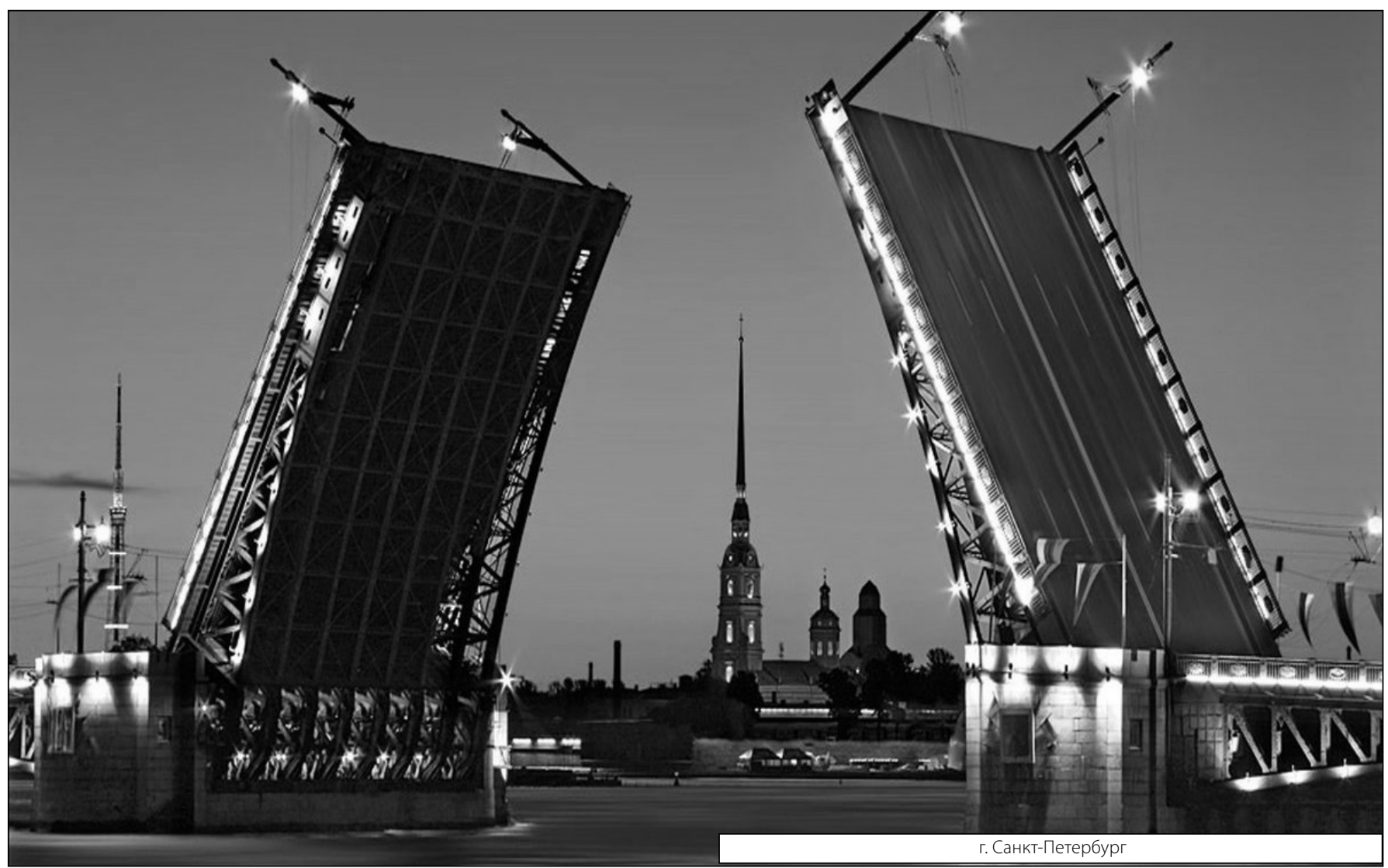

